\title{
SOCIO-AFFECTIVE STRATEGIES IN ENHANCING STUDENTS' SPEAKING MOTIVATION
}

\author{
Lystiana Nurhayat Hakim. Universitas Perjuangan Tasikmalaya. \\ tianaghea@gmail.com \\ Yuan Suniar. Universitas Perjuangan Tasikmalaya. \\ yuansuniar@yahoo.com
}

\begin{abstract}
Abstrak
Penelitian ini digunakan untuk menelusuri penggunaan strategi sosio-afektif untuk meningkatkan motivasi siswa dalam berbicara berbahasa Inggris. Oleh karena itu, penelitian ini bertujuan untuk mencari cara guru dalam penggunaan strategi sosio-afektif untuk meningkatkan motivasi siswa dalam berbicara berbahasa Inggris dan untuk mendeskripsikan persepsi siswa terhadap strategi sosio-afektif dalam meningkatkan motivasi berbicara. Studi kasus digunakan sebagai desain penelitian dalam kajian ini. Data dikumpulkan melalui observasi kebiasaan kelas belajar, wawancara, dan kuesioner. Selanjutnya, penulis menggunakan data teknik triangulasi untuk membuat hasil penelitian menjadi semakin valid. Temuan dari penelitian ini menunjukan bahwa ada enam cara yang menggunakan strategi sosio-afektif dalam pembelajaran speaking; mengurangi kecemasan ssiwa, mendorong siswa untuk berbicara, pengontrolan emosi siswa, bertanya, kerjasama dengan siswa yang lain, dan empati terhadap rekan yang lainnya. Data yang dikumpulkan juga mengindikasikan bahwa siswa memiliki persepsi positif dalam menggunakan strategi sosio-afektif untuk meningkatkan motivasinya dalam berbicara.
\end{abstract}

\section{Katakunci: Strategi Socio-Afektif, Pembelajaran Speaking, Motivasi}

\section{INTRODUCTION}

Speaking is one of the basic competencies that are learnt in school especially in Indonesian senior high school. In speaking, there are several aspects that should be mastered such as grammar, vocabulary, comprehension, fluency and pronunciation, and students should have many ideas in their mind before they speak (Gani et al, 2015, p. 17). Furthermore, Behtash (2016, p. 210) stated that speaking fluently and accurately is the most important skill in learning language, and it has a main role in learning English.

Speaking is an important skill which can support not only by the other skills such as listening, reading, and writing (Richard \& Renandya (2002) in Behtash et al (2016, p. 209); Celce-Murica (2001) in Derakhshan et al (2016, p. 177) but also grammar, vocabulary, comprehension, fluency, and pronunciation (Khamkhien (2010) in Behtash et al (2016, p. 210).

Unfortunately, there are many Indonesian students encounter some problems in speaking such as their lack in using appropriate tenses, their lack in using vocabulary, their difficulty in developing idea of speaking, and their lack in pronouncing the word. Furthermore their selfconfident and motivation in speaking is low. Consequently, they tend to choose keep silent rather than participate in active communication with their peers or teachers.

Tajzadeh, et. al (2013) said that almost Asian students are difficult to show their opinions, uncomfortable, and almost no questions in the class (p. 670). Related to those problems, it is urgent for the teacher and researcher to overcome it and find best solution. 
The most important goal of teacher in teaching speaking is to enable students to use English for communication Derakhshan et al (2016, p. 178). He also stated that there are several obstacles in learning speaking; incompatibility between class material and course, the teacher do not facilitate well in practicing speaking in the classroom, and the teacher should have known student' need and interest in learning speaking. Derakhshan et al (2016, p. 178) stated that to develop the students' speaking skill, the teacher in teaching English can use several types of speaking performance, there are:

\subsection{Imitation}

In this session, the students should pay attention to certain vowel sounds and intonation, afterward they should imitate correctly. Foreign language classes, rote pattern drills often evoke surface imitation: a repetition of sounds by the students without the vaguest understanding of what the sounds might possibly mean Brown (2007, p.43)

\subsection{Responsive}

In this session, the teacher should make the students active in the classroom. They also should reply the teacher's questions and comments. Furthermore, the students should participate in the classroom.

\subsection{Intensive}

The students learn not only how to initiate a conversation but also how to respond to another's initiating utterance Brown (2007, p. 48).

\subsection{Transactional dialogue}

The teacher should let the student to participate in conversation. It aimed to take and give information between listeners and hearer.

\subsection{Interpersonal dialogue}

In this session, the students should make a conversation with their friend not only in a formal but also in non- formal language. It aimed to create a habit in making conversation that they can use language casually.

\subsection{Extensive}

To improve the students speaking skill, they should practice regularly. First, the learners should expand their general vocabulary and then they can improve their domain of vocabulary by listening from simple to complex sentences, by reading short story or magazine.

In addition, in teaching English, the teacher should know that there are several factors influencing student's speaking, proposed by Derakhshan et al (2016, p. 181) such as cognitive factors, linguistic factors, and affective factors.

Cognitive factors are about how the students through speaking processes include conceptualization, formulation, and articulation Levelt (1989) as cited in Derakhshan et al (2016, p. 181). Linguistic factors are about how the students apply grammar in their speaking. They include several features like pronunciation, grammar, and vocabulary. Affective factors are about students' emotion and feel while teaching learning process, include self-esteem, selfefficacy, inhibition, risk taking, anxiety, empathy, and motivation Brown (2007, p. 154).Smilar with Brown (2007, p. 154), Derakhshan et al (2016, p. 181) also stated that anxiety, self-restriction have an influence on learners' oral proficiency.

Affective factors are about students' emotion and feel while teaching learning process, include self-esteem, self-efficacy, inhibition, risk taking, anxiety, empathy, and motivation Brown (2007, p. 154).Smilar with 
Brown (2007, p. 154), Derakhshan et al (2016, p. 181) also stated that anxiety, self-restriction have an influence on learners' oral proficiency.

However, the most important point is giving motivation in teaching learning activity. Motivation is important aspect that can lead students learn successfully. Brown (1987) as cited in Ziahossaeni (2008, p.90) stated that motivation is a key in learning.

In addition, Bakar (2014, p. 723-724) argued that motivation is an intricate part of human psychology and behaviour which can give influences to the individual choice include how they think and feel about the task, how they solve the problems of the task, and how consistent they learn in the class and do all the tasks. Furthermore, Ryan and Deci (2000, p. 54) stated when the learners have high motivation it means they will do something, whereas unmotivated learners, they will have no inspiration to act.

Motivation is divided into two types; intrinsic motivation and extrinsic motivation. The quality of experience and performance can be very different when one is behaving for intrinsic versus extrinsic reasons. Ryan and Deci (2000, p. 55) stated that intrinsic motivation is the fact of doing an activity for itself, and the pleasure \& satisfaction derived from participation. They also stated that extrinsic motivation is related to a wide variety of behaviours which are engaged in getting a goal for their own sake. To indicate the differences between intrinsic factors and extrinsic factors Bakar (2014, p. 724) explained that the examples of intrinsic factors are attitudes, interests, and intelligence; and the examples of extrinsic factors are environmental factors, it consists; family, school, or community environment.
Contrast with intrinsically motivated students, who work for the feeling of satisfaction or accomplishment, extrinsically motivated students will perform mainly for the attainment of a desire external reward or to avoid external punishment Wang (2008, p. 634).

Besides, there are many studies which identified the students' motivation in learning process between the student who has high motivation and low motivation. Bakar (2014, p. 723-724) argued that motivated learners will be more successful than unmotivated learners, it can be seen from their behaviour. He said that motivated learners will learn diligently, interest in solving the problems of the task, feel no bored while teaching learning process, feel confident in doing the task, focus and pay attention to the lesson and have fun in learning process.

However, the other researchers (wigfield \& Eccles, 2002; Wigfield \& Waguer, 2005) also stated in Saeed ( 2012, p. 254) that Intrinsic motivated students have high of achievement levels, low in anxiety levels, \& high perception of competence in learning than unmotivated students. The role of motivation in learning process is really important to achieve the goals. Without high motivation, the learners with a good notable abilities they cannot achieve the goals Babaee (2012, p. 1). It can be concluded that students need an ample motivation to learn English successfully especially in improving their speaking ability.

\begin{tabular}{cll}
\hline Groups & Subgroups & \multicolumn{1}{c}{$\begin{array}{c}\text { Learning } \\
\text { strategies }\end{array}$} \\
\hline & Planning & $\begin{array}{l}\text { Advance } \\
\text { organizer, directed } \\
\text { attention, selective } \\
\text { attention, self- } \\
\text { metacogniti }\end{array}$ \\
ve & & $\begin{array}{l}\text { management, } \\
\text { functional } \\
\end{array}$ \\
\cline { 2 - 3 } & & planning \\
\cline { 2 - 3 } & & Self-monitoring \\
\cline { 2 - 3 } & & Self-evaluation \\
\hline
\end{tabular}


Due to this problem, there is a strategy that can be used to motivate students in learning, namely socio affective strategy. Habte - Gabr (2006) in Hamzah, et.al (2009, p. 690) proposed that socio-affective strategies are strategies that using feeling in teaching learning process include empathy between the learners and the instructors to build a positive effect because the relationship between of them is important. They also stated that socio-affective strategies are the most effective strategies to increase student's learning.

Socio-affective strategies are about the difference of mental and behavioural of learners which can improve the students learning Ata (2016, p. 170). O’Malley and Chammot (1990) in Parra (2010, p. 151) define socio-affective strategies as strategies that help learners regulate and control emotions, motivations, and attitudes toward learning, as well as help learners learn through contact and interaction with others. Besides, Oxford (1990) in Parra (2010, p. 151) and Tse (2011, p. 30) said that affective strategies have a duty to control the learner's feeling and attitudes such as anxiety and socio strategies have a duty to build an interaction with the other to learn language such as asking question and becoming awareness.

Socio-affective strategies are a part of language learning strategies to learn language successfully. There are many researchers classified language learning strategies. Vlckova, et al (2013, p. 98-99) compared Rubbin's language learning strategies, O’Malley \& Chammot's language learning strategies, and Oxford's language learning strategies as follow:

Table 1 Rubbin's Language learning Strategies

\section{Groups of Subgroups of strategies} strategies

\begin{tabular}{ll}
\hline $\begin{array}{l}\text { Direct } \\
\text { strategies }\end{array}$ & $\begin{array}{l}\text { Clarification/verification, } \\
\text { monitoring, } \\
\text { guessing/inductive } \quad \begin{array}{c}\text { memorization, } \\
\text { deductive reasoning, practice }\end{array}\end{array}$ \\
\hline Indirect & $\begin{array}{l}\text { Creating opportunities for practise, } \\
\text { strategies }\end{array}$ \\
\hline
\end{tabular}

Table 2 O'Malley and Chammot's Language Learning Strategies

\begin{tabular}{|c|c|c|}
\hline $\begin{array}{l}\text { Main } \\
\text { group }\end{array}$ & $\begin{array}{c}\text { Strategy } \\
\text { groups }\end{array}$ & Subgroups \\
\hline \multirow{3}{*}{ Direct } & Memory & $\begin{array}{l}\text { Creating mental } \\
\text { linkages, applying } \\
\text { images and sounds, } \\
\text { reviewing well, } \\
\text { employing action } \\
\end{array}$ \\
\hline & Cognitive & $\begin{array}{l}\text { Practising, receiving } \\
\text { and sending messages, } \\
\text { analyzing and } \\
\text { reasoning, creating } \\
\text { structures for input } \\
\text { and output }\end{array}$ \\
\hline & Compensation & $\begin{array}{l}\text { Guessing intelligently, } \\
\text { overcoming } \\
\text { limitations in speaking } \\
\text { and writing. }\end{array}$ \\
\hline \multirow{3}{*}{ Indirect } & Metacognitive & $\begin{array}{l}\text { Centering your } \\
\text { learning, arranging } \\
\text { and planning your } \\
\text { learning, evaluating } \\
\text { your learning } \\
\end{array}$ \\
\hline & Affective & $\begin{array}{l}\text { Lowering your } \\
\text { anxiety, encouraging } \\
\text { yourself, taking your } \\
\text { emotional temperature }\end{array}$ \\
\hline & Social & 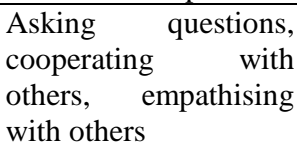 \\
\hline
\end{tabular}

Table 3 Oxford's classification learning Strategies

\begin{tabular}{cll}
\hline Groups & Subgroups & Learning strategies \\
\hline Cognitive & - & Repeatation, \\
& & resourcing, \\
& translation, grouping, \\
& note taking, \\
& summarizing, \\
& deduction, \\
& & recombination, \\
& translation, imagery \\
& & and auditory \\
& & representation, \\
& & keyword method, \\
& & contextualization, \\
& & elaboration, transfer, \\
& & inference \\
& & - \\
\hline Socio- & Question for & \\
affective & clarification & \\
\cline { 2 - 3 } & Cooperation & - \\
\hline
\end{tabular}




\section{Self-talk}

Based on those classifications, in every subcategory or subgroup, it has a point that the teacher can develop and improve strategies in teaching. The teacher can make teaching learning process creatively to make the students enjoy in the classroom. For example, Hamzah, et.al (2009, p. 692) make some steps of teaching listening using socio-affective strategies as follow:

1. Pre listening: the students write about their feeling and talk about their feeling to peers, after that they lower their anxiety, relaxation, deep breathing, and stretching, and finally repeating positive statement.

2. While teaching: explaining of the task, asking for clarification, helping peers to do the task exchanging ideas group and pair work.

3. Post listening: Check the answers within groups, self-reward and encouragement, and give a comment on the task to get feedback from teacher and peers.

Besides, Ata (2016, p. 183) has different way in making step in teaching English textbook and official programs using socio-affective strategies, as follow :

1. Make the learners to overcome their shyness.

2. Let the learners interact and try to speak fluently without worry make a mistake.

3. Make the learners enjoy while learning process and enjoy the humorous aspect.

4. Let the learners express their opinion, compare, and respond to the different attitudes.

5. Encourage learners to ask for help.

Similar with Ata (2016, p. 183) and
Hamzah, et al (2009, p. 692), Bakar (2014, p. 730) also proposed some steps in teaching speaking using socio-affective strategies which improve learning motivation of the students:

1. Create an interest of student's in new atmosphere before start the lesson.

2. Develop a positive emotional not only in giving the material but also a value to the students.

3. Let the students make an interaction with other \& cooperate to solve the problem, for example: make preparation before show their performance in front of the class.

4. Create an image in foreign things to be an ordinary, it aimed to decrease the student's anxiety.

5. Make students's belief with their own/develop their self-confidence when they should speak in front of the class/show their performance.

Socio-affective strategies are the strategies that can apply for every teacher in teaching learning process. Besides, they will give many advantages for the teachers and the students. Tajzadeh, et.al (2013, p. 670-673) explained that the advantages in using socioaffective strategies are can lower anxiety by using some mental technique and can solves the problems through teacher-student or peer interaction. Besides, socio-affective strategies can lead a better performance in speaking ability.

In addition, Hamzah et al(2009, p. 695) stated that socio-affective strategies give a positive effect to the learners such as lead the learners to better comprehension in listening class, risk taking, self-confident, and more interaction with other to solve the problems. Similar with Hamzah et.al (2009, p. 695) and Ata (2016, p. 184) also concluded that socio- 
affective strategies give the advantages in teaching learning activity. They stated that socioaffective strategies can help the learners when the teacher can improve the material with humorous. Furthermore, the learners will like the material, they will have good interaction with others, and they will enjoy the humorous while teaching learning process.

Unfortunately several studies reported the same reports that socio-affective strategies seldom used in research by researcher. Tajzadeh, et.al (2013, p. 670) asserted that the most frequently used in research are cognitive and meta-cognitive strategies. Therefore, this study tried to find out how socio-affective strategies can motivate students in speaking.

\section{RESEARCH METHODOLOGY}

In this study, qualitative study was used based on the nature of the object studied and underlying goals of the research. The researcher chose case study as the design to analyse the topic of study. According to Ary, et al (2010, p. 29) case study is a kind of qualitative research and it focuses just in a single unit such as in one individual, one group, one organization, or one program. The researcher used this research design because she just focuses in one phenomenon. It is the use of socio-affective strategies to enhance students' motivation in speaking. The researcher used nonprobability sampling which there is non-random procedures in selecting the member of sample. Ary, et al (2010, p. 155) stated that nonprobability sampling is method of selection sample which elements are not chosen by chance procedures. An English teacher and 21 students were determined by the researcher as the sample of this study. This study was conducted in one
Islamic Boarding school in West Java.

To undertake the study, the researcher firstly conducted observation; the researcher recorded the process of teaching learning activities, wrote important information, and took several pictures. Here is the observation checklist. Secondly, the researcher interviewed the teacher related to the strategy in teaching speaking and the use of socio-affected strategies in the classroom. Thirdly, the researcher gave students the questionnaire. The purpose is to find out students' perceive on socio affective strategies to enhance their motivation in speaking. After gathering the data from observation, interview, and questionnaire the researcher transcribed the result, summarized the findings and drawn some conclusions from such findings.

\section{RESEARCH FINDINGS}

The purpose of this study are to describe how does the teacher use socio-affective strategies to enhance students' motivation in speaking and to describe how do the students' perceive on socio-affective strategies to enhance their motivation in speaking. To answer the first research question about the teacher's way in using socio-affective strategies in enhancing students' motivation in speaking, the researcher used classroom observation checklist and semi structured interview. The following table showed the results from observation and interview:

Table 4 the result of Observation and Interview

\begin{tabular}{|c|c|c|}
\hline No & Strategies & Activities \\
\hline 1. & $\begin{array}{l}\text { Reducing } \\
\text { students' } \\
\text { anxiety }\end{array}$ & $\begin{array}{l}\text { 1. Make students relax } \\
\text { whenever they feel } \\
\text { afraid of using English } \\
\text { 2. Let students take a } \\
\text { breath to minimize } \\
\text { their anxiety before } \\
\text { their performance in } \\
\text { front of the class. }\end{array}$ \\
\hline 2. & $\begin{array}{l}\text { Encourage } \\
\text { themselves }\end{array}$ & $\begin{array}{l}\text { 1. Encourage students to } \\
\text { speak English even } \\
\text { when they are afraid of } \\
\text { making a mistake. }\end{array}$ \\
\hline
\end{tabular}




\begin{tabular}{|c|c|c|}
\hline & & $\begin{array}{l}\text { 2. Give students a } \\
\text { reward/reinforcement } \\
\text { or treat when they do } \\
\text { well in English } \\
\end{array}$ \\
\hline 3. & $\begin{array}{l}\text { Controlling } \\
\text { emotinal }\end{array}$ & $\begin{array}{l}\text { Let students to talk to } \\
\text { someone else about how } \\
\text { they feel when they are } \\
\text { learning English. }\end{array}$ \\
\hline 4. & Asking question & $\begin{array}{l}\text { 1. Let students ask } \\
\text { questions in English. } \\
\text { 2. Let students ask the } \\
\text { other person to slow } \\
\text { down or say it again if } \\
\text { they don't understand } \\
\text { something in English }\end{array}$ \\
\hline 5. & $\begin{array}{l}\text { Cooperating } \\
\text { with others }\end{array}$ & $\begin{array}{l}\text { 1. Make students practice } \\
\text { English with other } \\
\text { students } \\
\text { 2. Make students work } \\
\text { successfully in a group }\end{array}$ \\
\hline 6. & $\begin{array}{l}\text { Empathising } \\
\text { with others }\end{array}$ & $\begin{array}{l}\text { Make students to } \\
\text { volunteer in activities }\end{array}$ \\
\hline
\end{tabular}

Based on the table above, it showed that the results from observation were similar with Oxford's classification. Oxford (1990) in Vlckova (2013, p. 98-99) stated that there are six strategies in socio-affective strategies; reducing students' anxiety, encouraging them to speak, controlling emotional, asking question, cooperating with others, and empathizing with others. To answer the second research question about the student perception on socio-affective strategies to enhance their motivation in speaking, the researcher used questionnaire. The following table is the result of questionnaire:

Table 5 the result of Questionnaire

\begin{tabular}{|c|c|c|c|}
\hline \multirow{2}{*}{ No } & \multirow{2}{*}{ Statements } & \multicolumn{2}{|c|}{ Answer (\%) } \\
\hline & & Yes & No \\
\hline 1. & $\begin{array}{l}\text { I try to relax whenever I feel } \\
\text { afraid of using English }\end{array}$ & 95 & 5 \\
\hline 2. & $\begin{array}{l}\text { I take a breath/deep breathing } \\
\text { to minimize my anxiety } \\
\text { before I do my performance } \\
\text { in front of the class. }\end{array}$ & 67 & 33 \\
\hline 3. & $\begin{array}{l}\text { I feel motivated to encourage } \\
\text { myself to speak English even } \\
\text { when I am afraid of making a } \\
\text { mistake. }\end{array}$ & 81 & 19 \\
\hline 4. & $\begin{array}{l}\text { I Give myself a reward or } \\
\text { treat when I do well in } \\
\text { English }\end{array}$ & 86 & 14 \\
\hline 5. & $\begin{array}{l}\text { To practise my speaking I talk } \\
\text { to someone else about how I }\end{array}$ & 52 & 48 \\
\hline
\end{tabular}

\begin{tabular}{clcc}
\hline \multicolumn{4}{l}{$\begin{array}{l}\text { feel when I am learning } \\
\text { English. }\end{array}$} \\
\hline $6 . \quad \begin{array}{l}\text { I always ask the other person } \\
\text { to slow down or say it again if } \\
\text { I don't understand something } \\
\text { in English. }\end{array}$ & 86 & 14 \\
\hline 7. & $\begin{array}{l}\text { I try to practice English with } \\
\text { other students. }\end{array}$ & 86 & 14 \\
\hline 8. & I ask questions in English. & 81 & 19 \\
\hline 9. & $\begin{array}{l}\text { I like to volunteer in } \\
\text { activities. }\end{array}$ & 62 & 38 \\
\hline $10 . \quad \begin{array}{l}\text { I tried my best to work } \\
\text { successfully in a group. }\end{array}$ & 86 & 14 \\
\hline Adopted and modified from Kahraman & & \\
\hline
\end{tabular}

(Adopted and modified from Kahraman (2013)

According to the table, the researcher concluded that almost students feel that socioaffective strategies helpful to enhance their motivation in improving their speaking ability. Besides, there are more than $50 \%$ student agree that socio-affective strategies help them to enhance their motivation in speaking. It was relevant with Tajzadeh, et.al (2013, p. 670-673) that the advantages in using socio-affective strategies are can lower anxiety by using some mental technique and can solve the problems through teacher-student or peer interaction. Socio-affective strategies also can lead a better performance in speaking ability.

\section{CONCLUSION}

Related to the result of this study, the researcher conclude that in using socio-affective strategies, the teacher used 6 strategies such as reducing students' anxiety, encouraging them to speak, controlling emotional, asking question, cooperating with other and empathising with other. The students also have positive perception toward the use of socio-affective strategy in teaching speaking. They thought that socioaffective strategies helped them to enhance their motivation and confident in speaking.

\subsection{Suggestion}

Referring to the conclusions, there are several suggestions for the teachers, students, and other researcher. Firstly, for English teachers, beside they need to choose appropriate 
teaching method and technique in speaking, they also need to implement socio-affective strategy to improve students' motivation and confident in speaking. Secondly, students should more brave in showing their ideas and in sharing their ideas with their friends. Students also should increase their confident and intrinsic motivation in speaking.

Finally, other researchers can do further research in the field applying some other variables involving students' interest, motivation or curiousity, self-esttem, self- confidence, intelligent, and many others. Second, the result of this strategy can be used as an additional reference for a similar research with different variables and different population characteristics.

\section{REFERENCES}

Ata, T, A. (2016). Social-Affective Strategy Instruction in EFL Material: The Case of English Textbook and Official program in Tunisia. International of Humanities and Cultural Studies ISSN 23565926.2(4).169-192.

Ary,D. Jacobs, L, C. Scrensen, C. (2010). Introduction to Research in Education Eight Edition. Canada: Nelson Education, Ltd.

Babaee, N. (2012). Motivation in Learning English as a Second Language; A Literature Review. Canadian Journal for New Scholars in Education. 4(1). 1-7

Bakar, R. (2014). The Effect of Learning Motivation on the Student's Productive Competencies in Vocational High School, West Sumatra.International Journal of Asian Social Science.4(6).722-732.

Behtash, E, Z. Saed, A. Sajjadi, F. (2016).The Effect of Storytelling Technique on Speaking Ability of Female Iranian Intermediate EFL Learners.International Journal of Applied Linguistics \& English Literature.5(1).209-214.

Derakhshan, A. Khalili, A, N. Beheshti, F. (2016).Developing EFL Learner's
Speaking Ability, Accuracy and Fluency.English Language and Literature Studies.6(2).177-186.

Gani, S, A. Fajrina, D. Hanifa, R. (2015). Students' Learning Strategies for Developing Speaking Ability.Studies in English Language and Education.2(1).1629.

Guest, G. (2000). Field Methods. Sage Publications, Inc. 12(4).346-357.

Hamzah, M, S, G. Shamshiri, K. Noordin, N. (2009).Effect of Socio-Affective Strategy training on Listening Comprehension.European Journal of Social Sciences.11(4).690-697.

Kahraman. F,G. (2013). The Effective of SocioAffective Language Learning Strategies and Emotional Intelligence Training on English as a Foreign Language (EFL) Learners' Foreign Language Anxiety in Speaking Classes.Bilkent University.

Parra, Y. J. F. (2010). Explicit Teaching of Socio-Affective Language Learning Strategies to Beginner EFL Students.Ikala, Sevista De Lenguage \&Cultuza.15(24). 145-169.

Ryan, R. M., \& Deci, E. L. (2000). Intrinsic and Extrinsic Motivation: Classic Definition and New Directions. Contemporary Educational Psychology, 25, 54-67.

Ryan, R. M., \& Deci, E.L. (2000). SelfDetermination Theory and the Facilitation of Intrinsic Motivation, Social Development, and Well-Being. American Psychologist. 55(1) 68-78.

Saeed, S\& Zyngier, D. (2012). How Motivation Influences Student Engagement: A Qualitative Case Study. Journal of Education and Learning. 1(2). 252-267.

Tajzadeh, P. Khodabandehlou, M. Jahandar, S. Najafi, M. (2013).The Impact ofSocioAffective Strategies on Iranian Intermediate EFL Learner's Speaking Ability.Indian Journal of Fundamental and applied Science. 3(3).670-674.

Tse, A. Y. (2011). A Comparison of Language Strategies Adopted by Secondary and University Students in Hong Kong. International Journal of Business and 
Social Science.2(11).29-34.

Vlckova, K. Berger, J. Volkle, M. (2013). Classification Theories of Foreign Language Learning Strategies: An Exploratory Analysis. Studia Paedagogica. 18(4).94-113.

Wang, F. X. (2008). Motivation and English Achievement: An Exploratory and Confirmatory Factor Analysis of a New Measure for Chinese Students of English Learning. North American Journal of Psychology. 10(3). 633-646.

Ziahossaeini, S,M. \& Salehi, M. (2008).An Investigation of the Relationship between Motivation and Language Learning Strategies.Special Issue, English. 41. 85107. 